\title{
Calculation of the Modulus of Elasticity with Using Natural Frequency Formula and Updated Finite Element Analysis Of Automotive Rear Lamp Lens
}

\author{
Erhan $\mathrm{Ay}^{1}$, Barış Ediz ${ }^{1}$, Taner $\mathrm{Çal}^{1}$ and Sevda Telli Çetin ${ }^{2}$ \\ 0000-0001-9621-6030, 0000-0002-2704-7090, 0000-0003-3651-7872, 0000-0002-3281-9112
}

${ }^{1}$ R\&D Department/Magneti Marelli Mako Elektrik Sanayi ve Ticaret A.S., Turkey

${ }^{2}$ Mechanical Engineering Department/Uludağ University, Turkey

\begin{abstract}
In this study; the weight of the modal accelerometer used in the Roving Hammer Impact Test Method was added in the finite element analysis (FEA) and the undamped modal analysis of the automotive rear lamp lenses were performed. Also, calculated new Elastic Modulus for Polymethylmethacrylate (PMMA) material with using natural frequency formula and this value was used in the ANSYS WB ${ }^{\circledR}$ program and the undamped modal analysis was repeated. After that, frequency response functions (FRFs) of an automotive rear lamp lens were obtained by using Roving Hammer Impact Test Method. At the same time; dynamic characteristics of the structure, natural frequencies, damping ratios and mode shapes were obtained. Damping ratios were calculated from the FRF's by using the Half Power Method. Finally, experimental modal analysis (EMA) and FEA results were compared.
\end{abstract}

Keywords: Automotive Rear Lamp, Finite Element Analysis, Frequency Response Function (FRF), Half Power Method, Impact Hammer Test Method, Experimental Modal Analysis

\author{
* Corresponding author \\ Erhan Ay \\ erhan.ay@magnetimarelli.com
}

Adress: Magneti Marelli Mako Elektrik Sanayi ve Ticaret A.Ş. Organize Sanayi Bölgesi Yeşil Cad. No:28 16159, Bursa, Turkey

Tel:+902242195995

Researh Article

Manuscript Received 18.03.2019

Revised 02.05.2019

Accepted 13.05.2019

Doi: 10.30939/ijastech..541253

\section{Introduction}

The behavior of the structures used in engineering during the design phase under the influence of static and dynamic forces is very important. In order to examine the behavior of the structures under dynamic forces, the free vibration characteristics should be determined in the first stage. The free vibration characteristics are the natural frequencies, the damping ratios and the mode shapes of the structure. The comparison of the frequencies of the forces coming to the structure and the free vibration frequencies is important for the resonance event. In addition, the investigation of the response of structures against dynamic forces is very important to determine how the structure under the influence of these forces will behave.

This study was carried out to show the importance and applicability of experimental modal analysis (EMA) method in automotive lighting sector.

In recent years, EMA has become an increasingly researched topic. Especially with the development of computer technology nowadays, computer aided measuring devices allow this process to be done faster.

The main reasons for such an experimental method are; - determining whether the actual acceptance of the assumptions made during the theoretical analysis of the structures has been achieved,

- experimentally determine the dynamic characteristics of the systems that have difficulty in making theoretical analysis and

- identifying the status of used and / or damaged structures [1].

Yaman (2012) in his study, first of all, wheel structure is introduced and literature survey on modelling of wheel is given. After that, created finite element model of a light commercial vehicle wheel validated by experimental modal analysis on free-free boundary condition. Also, in order to simulate axle-wheel connection, wheel analyzed on clamped at the spindle boundary condition with finite element 


\section{Material and Method}

analysis and experimental modal analysis approach. Then, natural frequencies? And mod shapes? Comparison is given between finite element and experimental modal analysis on clamped at the spindle boundary condition. At the end, design change suggestion is given provided that wheel have greater natural frequency than $350 \mathrm{~Hz}$. Even though $300 \mathrm{~Hz}$ frequency is recommended as vehicle interior noise limit, in order to take the worst case into account the limit is determined as $350 \mathrm{~Hz}$ [2].

Şekerci (2013) in his study, rotor blades which have a significant effect on the performance of helicopter, are discussed. Natural vibration frequencies of rotor blades and modes were examined with the help of software ANSYS WBß computationally. Natural frequency and modes of rotor blades which were examined with the method finite element analysis, were determined with the method empirical modal analysis. Then, these findings were compared with each other's. The results which were obtained with the method finite element analysis, were verified with the method empirical modal analysis [3].

Baldan (2018) in his study, dynamic parameters of fan structure and single blade structure was determined by using experimental and theoretical modal analysis methods. Within the scope of thesis, structure of fan is introduced and literature research was made concerning experimental and theoretical modal analysis methods. Single blade structure is derived from fan structure by cutting section. Results is compared for single blade structure by performing experimental and theoretical modal analysis with correlation. Then for complete fan structure, results are examined by performing experimental and theoretical modal analysis methods. As modal test evaluation criteria, peak points, phase change of frequency response graphics and mode shapes is evaluated by comparing results. By comparing results for these structures, performing experimental and theoretical modal analysis only for single blade structure will be sufficient to determine dynamic behaviors for complete of fan structure. As result of research, it is seen that dynamic characteristics obtained from experimental modal results are close to theoretical modal analysis results [4].

The main aim of this study comparison of FEA results with the results of the impact hammer test for automotive rear lamp lenses made of PMMA material and verification of material elasticity. The weight of the modal accelerometer used in the tests was added in the FEA and the undamped modal analysis of the structure was made. At the same time, Modulus of Elasticity of the PMMA material in the material datasheet was changed and new Modulus of Elasticity of this material was calculated according to natural frequency formula. Calculated Modulus of Elasticity was used and FEA was repeated. Finally, EMA and FEA results were compared.

\subsection{FEA with added weight of the modal accelerometer of an Automotive Rear Lamp Lens}

While the FEA was performed, the weight of the modal accelerometer used in the tests was added and the undamped modal analysis was repeated. FEA was performed in free-free boundary conditions of PMMA material stop lenses and the band width was determined with the first 2 flexible body mode shapes. In Fig. 1, first flexible body mode shape is illustrated.

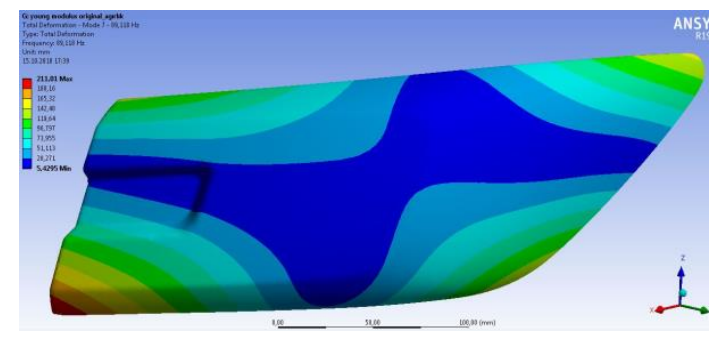

Fig.1. 1st Mode shape $-89.118 \mathrm{~Hz}$

In Fig. 2, second flexible body mode shape is illustrated.

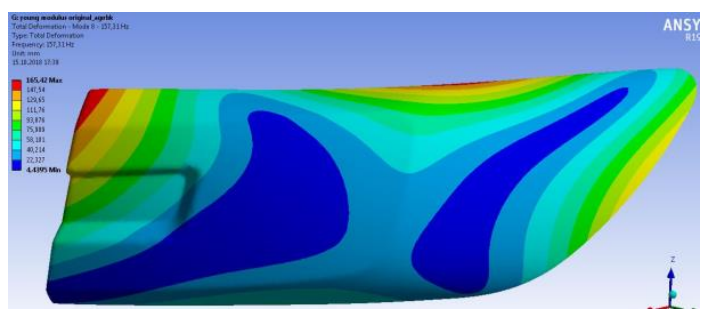

Fig. 2 2nd Mode shape $-157.31 \mathrm{~Hz}$

\subsection{Roving hammer impact test}

In Fig. 3, the final product marked on the response and the excitation points is hung using a single elastic rope from the specified single point test apparatus to capture the condition closest to the free-free boundary conditions. 

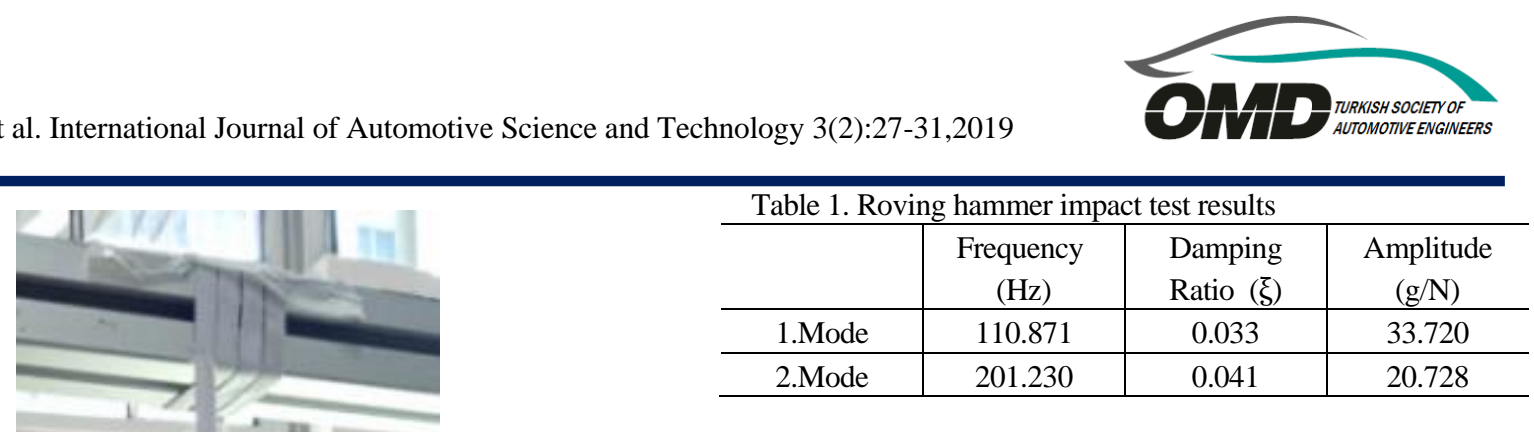

\subsection{Calculation new elasticity module for PMMA material}

As a result of the evaluations made, it was seen that the Elasticity Module, which is one of the required requirements for the material, is valid for the raw material during the FEA. As a result of the final product, it has been determined that the Modulus of Elasticity has changed and that a new Modulus of Elasticity is needed. For this, a new Modulus of Elasticity was calculated from the following formulation [6].

$\omega_{\mathrm{n}}=\sqrt{\frac{\boldsymbol{k}}{m}}$

$\omega_{1}$, the natural frequency value found in the FEA, $\omega_{2}$, the natural frequency value found in the EMA result. Since $\mathrm{k}$ is related to the Elasticity Module (E), this value will be used directly in the formula. In this case, $\mathrm{k}_{1}$ represents $3360 \mathrm{MPa}$ in the PMMA raw material datasheet, while $\mathrm{k}_{2}$ will be the calculated value. The masses (m) are equal.

$\frac{\omega_{1}}{\omega_{2}}=\frac{\sqrt{\frac{k_{1}}{m}}}{\sqrt{\frac{k_{2}}{m}}}=>\frac{\omega_{1}}{\omega_{2}}=\sqrt{\frac{k_{1}}{k_{2}}}$

Fig. 3. Test Sample - 1

FRF graphs were obtained from the determined points on the final product. Resonance points were determined by using FRF graphs and the damping ratios were calculated at these points. In Fig. 4, the first three modes of the roving hammer impact test method are illustrated.

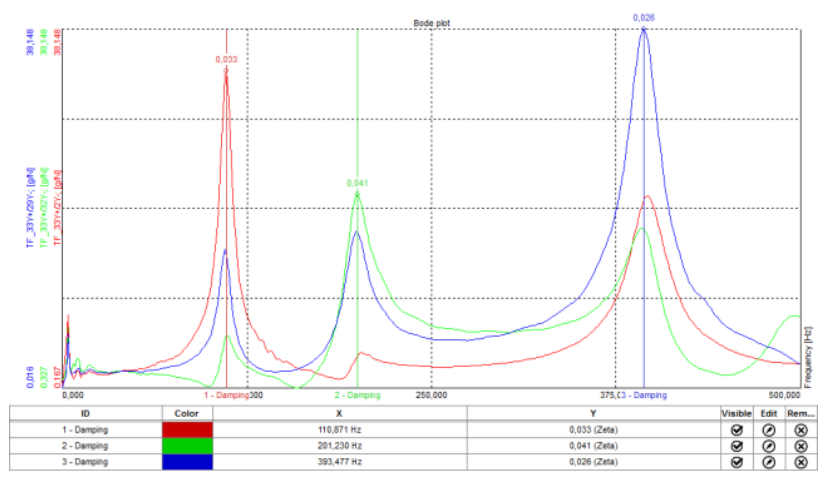

Fig. 4. Test sample FRF results

The damping ratios were calculated by using the half power method from the peaks in the Fig. 4 and results are illustrated in Table 1 [5].
From here;

$\frac{\mathbf{8 9}, \mathbf{1 1 8}^{\mathbf{2}}}{\mathbf{1 1 0 , 8 7 2 ^ { 2 }}}=\frac{3360}{\mathbf{k}_{2}} \Rightarrow \boldsymbol{k}_{2}=5200.491 \mathrm{MPa}$

This value was used in the ANSYS WB ${ }^{\circledR}$ program and the undamped modal analysis was repeated. The aim is to increase the rigidity of the structure and to approach the natural frequency values obtained in the test. In order to find this in the shortest way, the above formulation was made.

In Fig. 5 and Fig. 6 first and second flexible body mode shapes are illustrated respectively to the calculated new Modulus of Elasticity.

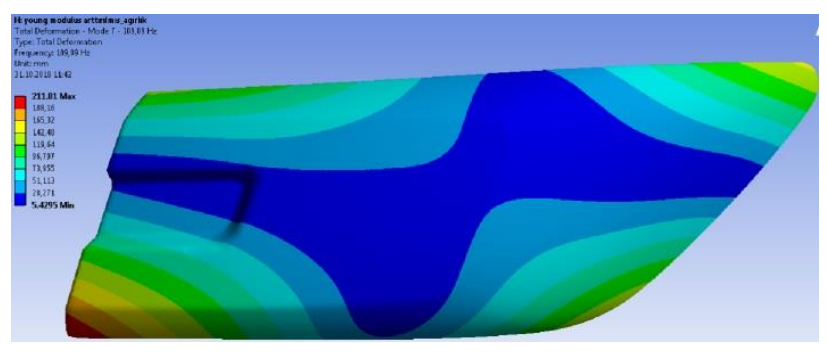

Fig. 5. 1st Mode shape $-109.89 \mathrm{~Hz}$ 


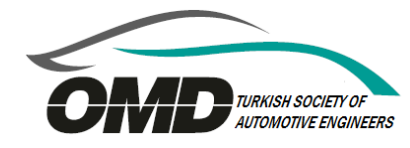

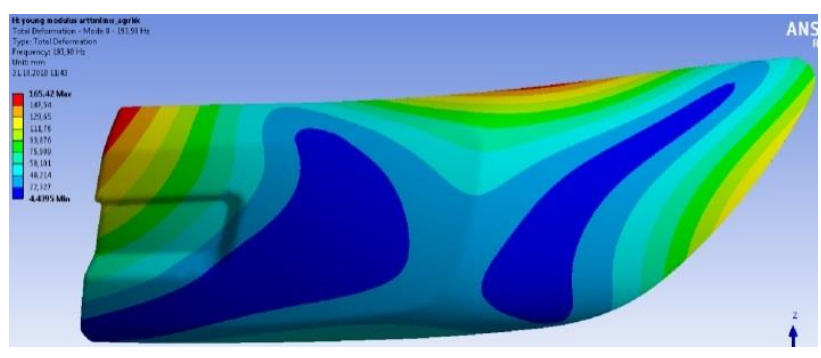

Fig. 6. 2nd Mode shape $-193.98 \mathrm{~Hz}$

\subsection{Validation of the new Modulus of Elasticity}

The calculated Modulus of Elasticity was made of the same material but different geometry used in the analysis of the automotive rear lamp outer lens and the results of the analysis and the test results were compared.

First of all, $3360 \mathrm{MPa}$ value for PMMA material was used in the ANSYS WB ${ }^{\circledR}$ program and the undamped modal analysis was performed. In Fig. 7 and Fig. 8 first and second flexible body mode shapes are illustrated respectively.

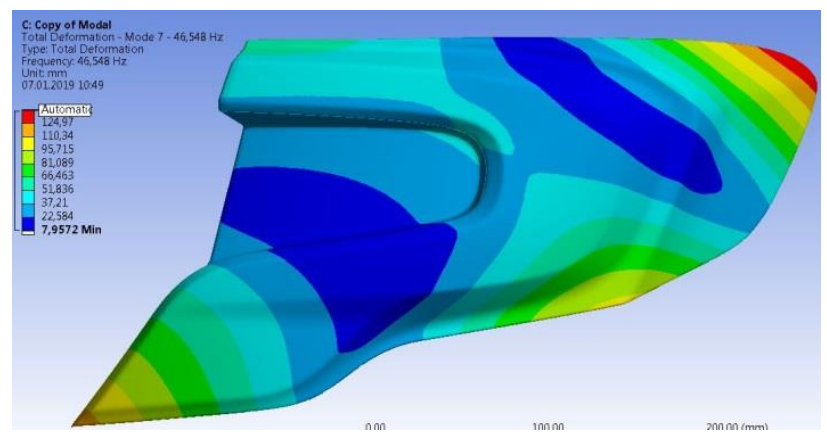

Fig. 7. 1st Mode shape $-46.548 \mathrm{~Hz}$

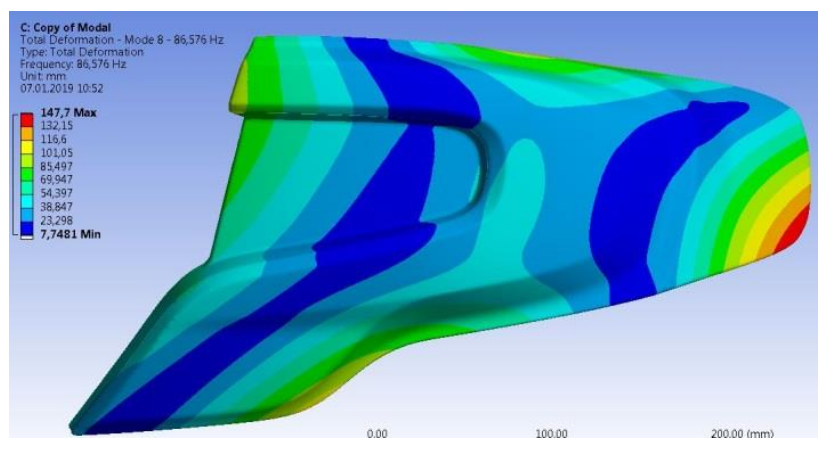

Fig. 8. 2nd Mode shape $-86.576 \mathrm{~Hz}$

After that calculation 5200.491 MPa value for PMMA material was used in the ANSYS WB ${ }^{\circledR}$ program and the undamped modal analysis was repeated. In Fig. 9 and Fig. 10 first and second flexible body mode shapes are illustrated respectively.

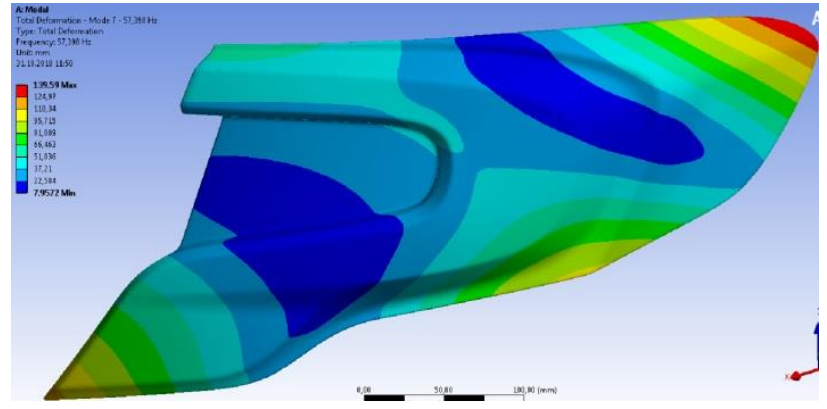

Fig. 9. 1st Mode shape $-57.398 \mathrm{~Hz}$

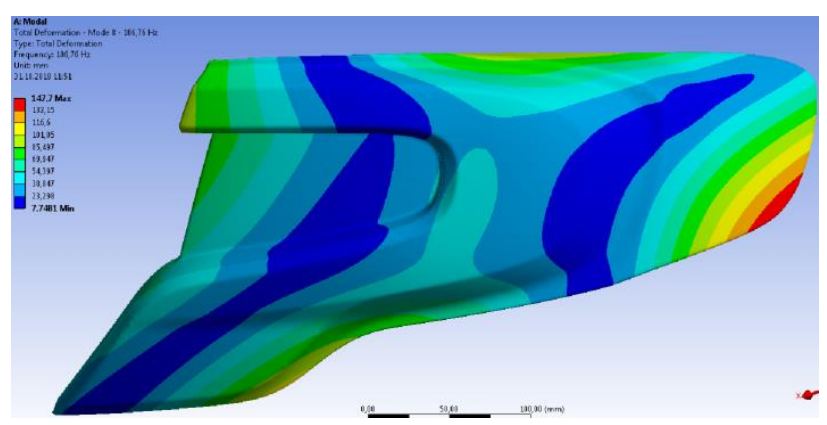

Fig. 10. 2nd Mode shape $-106.76 \mathrm{~Hz}$

\subsection{Roving hammer impact test for another rear lamp lens}

In Fig. 11, the final product marked on the response and the excitation points is hung using a single elastic rope from the specified single point test apparatus to capture the condition closest to the free-free boundary conditions.

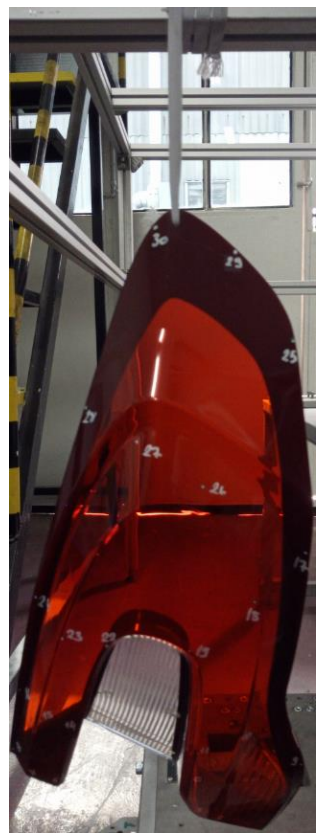

Fig. 11. Test Sample -2 
FRF graphs were obtained from determined the points on the final product. In Fig. 12, the first three modes of the roving hammer impact test method are illustrated.

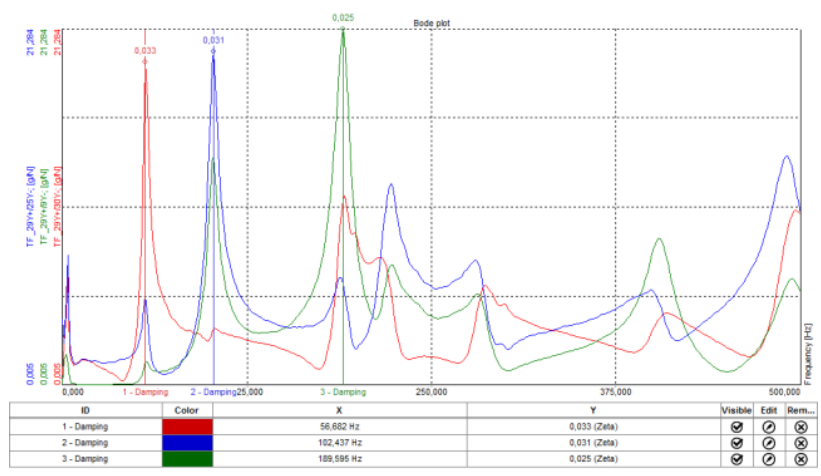

Fig. 12. Test sample FRF results (Roving Hammer Impact Test Method)

The damping ratios were calculated by using the half power method from the peaks in the Fig. 12 and results are illustrated in Table 2.

Table 2. Roving hammer impact test results

\begin{tabular}{c|c|c|c}
\hline & $\begin{array}{c}\text { Frequency } \\
(\mathrm{Hz})\end{array}$ & $\begin{array}{c}\text { Damping } \\
\text { Ratio }(\xi)\end{array}$ & $\begin{array}{c}\text { Amplitude } \\
(\mathrm{g} / \mathrm{N})\end{array}$ \\
\hline 1.Mode & 56.682 & 0.033 & 19.234 \\
\hline 2.Mode & 102.437 & 0.041 & 19.921 \\
\hline
\end{tabular}

The natural frequency of mode 1 is $56.682 \mathrm{~Hz}$ which corresponds to torsional motion and the damping ratio is 0.033 . The natural frequency of mode 2 is $102.437 \mathrm{~Hz}$ which corresponds to bending motion and the damping ratio is 0.041 .

\section{Conclusions}

The EMA results and the FEA results were compared and the automotive rear lamp lenses were found to be more rigid.

As a result of the comparisons made;

- the weight of the accelerometer should not be neglected,

- the material used in the data sheet of the PMMA material and used in the ANSYS WB $\AA$ program is valid for the raw material,

- this value does not apply to the final product,

- calculating a new modulus of elasticity for the final product

- $\quad$ using the value found in ANSYS WB® program,

- $\quad$ and undamped modal analysis has to be done again.

In this study modal testing and FEA methods have been applied on a part which is made of plastic material for which the dynamic material characteristics are rarely found in literature.
Table 3. FEA results vs roving hammer test results compare for test sample - 1

\begin{tabular}{c|c|c|c}
\hline & FEA & $\begin{array}{c}\text { Roving Hammer } \\
\text { Test }\end{array}$ & \\
\hline & Frequency $(\mathrm{Hz})$ & Frequency $(\mathrm{Hz})$ & $(\%)$ \\
\hline 1.Mode & 109.89 & 110.871 & 0.884 \\
\hline 2.Mode & 193.98 & 201.230 & 3.602 \\
\hline
\end{tabular}

Table 4. FEA results vs roving hammer test results compare for test sample - 2

\begin{tabular}{c|c|c|c}
\hline & FEA & $\begin{array}{c}\text { Roving Hammer } \\
\text { Test }\end{array}$ & \\
\hline & Frequency $(\mathrm{Hz})$ & Frequency $(\mathrm{Hz})$ & $(\%)$ \\
\hline 1.Mode & 57.398 & 56.682 & 1.247 \\
\hline 2.Mode & 106.76 & 102.437 & 4.049 \\
\hline
\end{tabular}

\section{References}

[1] Bayraktar. P., Türker. T. (2005). Deneysel modal analiz yöntemi ile düzlem çerçevelerin dinamik karakteristiklerin belirlenmesi. Deprem Sempozyumu, 23-25 Mart 2005, Kocaeli.

[2] Yaman, M. 2012. Hafif ticari bir araç jantının, sonlu elemanlar modelinin oluşturulması ve doğrulanması. Y. Lisans, İTÜ, Fen Bilimleri Enstitüsü, Makine Mühendisliği Anabilim Dalı, İstanbul.

[3] Şekerci, H. U. 2013. Bir hava aracı komponentinin dinamik karakteristiklerinin teorik ve deneysel modal analiz metoduyla belirlenmesi. Y. Lisans, İTÜ, Fen Bilimleri Enstitüsü, Uçak ve Uzay Mühendisliği Anabilim Dalı, İstanbul.

[4] Baldan, E. 2018. Otomotiv fan kanadının dinamik karakteristiğinin deneysel ve teorik modal analiz metotları ile incelenmesi. Y. Lisans, GTÜ, Fen Bilimleri Enstitüsü, Makine Mühendisliği Anabilim Dalı, Kocaeli.

[5] Anonymous, How to calculate damping from a FRF?. https://community.plm.automation.siemens.com/t5/TestingKnowledge-Base/How-to-calculate-damping-from-a-FRF/ta$\mathrm{p} / 355050$

[6] He, J., Hu, Z. (2001). Basic vibration theory: Modal analysis. Butterworth Heinemann. Oxford. 49-78. 